\title{
HOBBICI U BRAM EUROPY. POSTMODERNISTYCZNA GEOPOLITYKA W POWIEŚCI ARTURA KLINAUA PIKIELHAUBA
}

\author{
SIARHIEJ KAWALOU1 \\ (Lublin)
}

\begin{abstract}
Słowa kluczowe: współczesna proza białoruska, postmodernizm, geopolityka, stereotyp narodowy, opozycja Wschód-Zachód
\end{abstract}

Keywords: contemporary Belarusian prose, postmodernism, geopolitics, national stereotype, "East-West" opposition

\begin{abstract}
Abstrakt: Siarhiej Kawalou, HOBBICI U BRAM EUROPY. POSTMODERNISTYCZNA GEOPOLITYKA W POWIEŚCI ARTURA KLINAUA PIKIELHAUBA. „PORÓWNANIA” 11, 2012, Vol. XI, ss. 333-344, ISSN 1733-165X. Artykuł jest poświęcony ciekawej tendecji we współczesnej prozie bałoruskiej: oswojaniu przestrzeni europejskiej, przeniesieniu akcji poszczególnych utworów z blokowisk Mińska do kawiarenek Warszawy i klubów w Berlinie. Wyraźnym przejawem owej tendencji jest nowa powieść znanego artysty oraz pisarza awangardowego Artura Klinaua Pikielhauba (2011). Autor artykułu szuka odpowiedzi na pytanie: w jaki sposób poszerzenie granic geograficznych akcji odbiło się na cechach artystycznych utworu? Za najważniejszą cechę powieści badacz uważa oryginalną, czasem ironiczną interpretację problemu samoidentyfikacji narodowej, kwestię poszukiwania przez Białoruś swojego miejsca w Europie oraz odbioru Białorusinów przez inne narody europejskie.
\end{abstract}

Abstract: Siarhei Kavalou, HOBBITS AT THE GATE OF EUROPE. POSTMODERNIST GEOPOLITICS IN ARTUR KLINAU'S NOVEL PICKELHAUB. „PORÓWNANIA” 11, 2012, Vol. XI, pp. 333-344, ISSN 1733-165X. The article considers an interesting tendency of contemporary Belarusian prose: artistic adoption of the European geographical space, transfer of actions and narration from Minsk to cafés of Warsaw and clubs of Berlin. The vivid manifestation of this tendency is a new novel of a famous avant-garde artist and experimental writer Artur Klinaŭ Pickelhaube (2011). The author of the article investigates the matter how the expansion of the geographical borders influences the artistic peculiarities of the novel. The researcher thinks that the main value of the novel is a particular sometimes unusually ironic interpretation of the national self-identification, Belarus's searches of its place in Europe, perception of the Belarusians by other Europeans.

\footnotetext{
${ }^{1}$ Correspondence Address: skowalou@wp.pl
} 
Przez dłuższy czas proza białoruska kojarzyła się wyłącznie z tematyką wiejską; na wsi rozgrywała się akcja większości utworów Janki Bryla, Iwana Mieleża czy Iwana Szamiakina. Pod koniec XX wieku młodzi autorzy: Adam Hlobus, Uładzimir Ściapan, Maksim Klimowicz i inni rozpoczęli oswajanie przestrzeni miejskiej. Charakterystyczne, że przeniesienie akcji ze wsi do miasta łączyło się z przejściem od realizmu do postmodernizmu.

Ciekawą tendencją w białoruskiej prozie początku XXI wieku jest oswajanie przestrzeni europejskiej: akcja poszczególnych utworów prozatorskich przenosi się z blokowisk Mińska do kawiarenek Warszawy i klubów w Berlinie. Nowa powieść Artura Klinaua Pikielhauba (Szałom, 2011) jest wyraźnym przejawem owej tendencji.

Klinau jest znanym awangardowym artystą, redaktorem niezależnego pisma „pARTizan”. Jego debiut literacki Mińsk. Przewodnik po Mieście Stońca (Мінск. Малая падарожная кніжка па горадзе Сонца, 2008) przyjęty został z zainteresowaniem przez czytelnika białoruskiego (nieduży nakład książki rozszedł się błyskawicznie) i dość szybko trafił w ręce również czytelnika zagranicznego (powieść została przetłumaczona na języki niemiecki i polski, w Polsce ukazała się nakładem znanego wydawnictwa "Czarne”). Książka Mińsk. Przewodnik po Mieście Stoń$c a$, określona przez samego autora jako „powieść autobiograficzna”, w rzeczywistości jest połączeniem wspomnień z dzieciństwa $\mathrm{z}$ esejem kulturologicznym i właśnie dlatego odebrano ją nie jako pierwszy krok do poważnej kariery literackiej, ale raczej eksperyment twórczy, werbalny wariant albumu fotograficznego Miasto Stońca (Гораd COHu̧a, 2006). Całkiem inaczej wygląda sprawa z powieścią fabularną Pikielhauba, drukowaną we fragmentach w najlepszym białoruskim czasopiśmie literackim „Dziejaslou”, która trafiła na krótką listę nagrody im. Jerzego Giedroycia, przyznawanej przez Instytut Polski w Mińsku.

Trudno znaleźć we współczesnej literaturze białoruskiej utwór, który wyraźniej i bardziej świadomie niż Pikielhauba podnosiłby problem samoidentyfikacji narodowej, kwestię poszukiwania przez Białoruś swojego miejsca w Europie czy odbiór Białorusinów przez inne narody europejskie. Równie niełatwo znaleźć w literaturze białoruskiej tekst tak „otwarty” i przez to nadający się do badań nad techniką (sposobem) przedstawiania przestrzeni, literackiej topografii miast europejskich, artystycznego odzwierciedlenia opozycji Wschód-Zachód oraz innych aspektów współczesnej geopolityki. Tu warto raz jeszcze podkreślić, że nie jest to traktat kulturologiczny ani tom esejów podróżniczych, ale przedstawiająca barwnych bohaterów powieść awanturnicza, ironiczna i dowcipna.

Żeby zapoznać słuchaczy z fabułą nieznanego w Polsce utworu Klinaua, przytoczmy krótkie streszczenie autorstwa Małgorzaty Buchalik, tłumaczki wcześniejszych tekstów Klinaua, a także utworów Uładzimira Karatkiewicza, Uładzimira Niaklajeua, Ihara Babkoua czy Natalki Babinej na język polski: 
André, białoruski artysta z Mohylewa siedzi miesiąc na warsztatach w Bonn, robi plenerowe instalacje ze słomy, na pożegnalnym bankiecie usiłuje wyrwać jakąś rzeźbiarkę, ale się upija, następnego dnia na strasznym katzu idzie po buty dla teściowej, ale zamiast butów kupuje na pchlim targu piękną, błyszczącą pikielhaubę. Z braku kasy musi wracać autostopem i po drodze brać forsę od znajomych. Wkłada pikielhaubę i - jak to na katzu - postanawia już jej nie zdejmować. [...] W Hanowerze podrywa punkówę, jedzie z nią do Berlina, na skłot, w którym koczują białoruscy artyści; artyści przerabiają go na instalację "beznogi weteran prosi o wsparcie”, zarabiają kupę kasy i planują rozwinąć interes (kilkunastu beznogich weteranów w różnych punktach miasta), ale tu zonk: na André napadają neofaszyści i w trakcie bójki jeden z nich nadziewa się na ten, no, szpic [...], łysi koledzy przysięgają krwawą zemstę i André musi uciekać z Berlina, maskując pikielhaubę pod muzułmańską parandżą. [...]

Na granicy w Terespolu [...] celnik uprzedza, że pikielhauba jest dziedzictwem kultury i wjechać na Białoruś może, ale już wyjechać (bez specjalnych kwitów z ministerstwa kultury) nie, co oznacza, że André albo zrezygnuje z jej noszenia, albo z podróży po świecie. W Mińsku A. zaczynają prześladować obsesje: zwidują mu się, a potem śnią jacyś tajniacy, ucieczka podwórzami, pożar w gmachu KGB, atmosfera robi się ciężka, ale że A. cały czas nie trzeźwieje, można to jeszcze złożyć na karb katza-giganta.

W Mohylewie natomiast akcja wychodzi z katza i robi się całkiem już ostro, realistycznie i nieprzyjemnie: żona z teściową urządzają piekło, szef wydziału ASP, na którym wykłada André, „uprzedza” żeby lepiej skończyć z tą ekstrawagancką zabawą, a rektor wyrzuca A. z roboty i zapowiada odebranie pracowni. [...] André przygotowuje się do wyprowadzki pod most (dosłownie; robi tam sobie budkę ze starych szaf, przewozi rzeźby itd.), ale też do prawdziwie outsiderskiego życia: na początek włamuje się do gabinetu rektora, domalowuje na portrecie Łukaszenki hitlerowski wąsik i wtyka w ogołocone z kaktusów doniczki szczotki do mycia butelek [...] i w końcu pakuje się w partyzancką klasykę: postanawia wysadzić w powietrze most na Dnieprze. Zbiera i instaluje materiały wybuchowe, ale tymczasem pod mostem osiedla się widmo Dostojewskiego i bruździ...2

Już na podstawie tego streszczenia można stwierdzić, że pomysł autora jest nadzwyczaj oryginalny: założyć na głowę bohatera pikielhaubę i wysłać go do łukaszenkowskiej Białorusi. Daje to pretekst do licznych konfliktów, zwrotów akcji i testowania rozmaitych stereotypów ideologicznych. Dziwny postępek bohatera prowokuje wiele pytań (autor wyjaśnia go różnie, w zależności od sytuacji) i otwiera przed czytelnikiem nieograniczone pole swobodnej interpretacji. Tytułowy „шалом” (pikielhauba) w języku białoruskim oznacza zarówno wojskowy hełm, jak i hebrajskie „szalom” (pokój). Dlatego „шалом” na glowie Andrè jest jednocześnie wypowiedzeniem wojny i znakiem pokoju; wyzwaniem, rzuconym przez nadczłowieka nikczemnemu światu - i deklaracją całkowitej kapitulacji wobec świata; najlepszym projektem artystycznym bohatera - i ostatecznym zerwaniem z projektami artystycznymi; przemyślaną dywersją ideową - i zwykłym wa-

\footnotetext{
${ }^{2}$ M. Buchalik, Streszczenie powieści A. Klinaua Pikielhauba, rękopis autorski, s. 1.
} 
riactwem; „шалом" to wreszcie całkowity absurd, pustka do kwadratu, bezsens do trzeciej potęgi.

Nawet jeżeli przyjmiemy „wojskową" interpretację zachowań bohatera (nieprzypadkowo autor definiuje swój utwór również jako „powieść wojenną"), pojawia się pytanie: czym jest owa tajemnicza wojna, w jakim kierunku wyrusza i z kim zamierza walczyć białoruski artysta w pikielhaubie? Najprostsza odpowiedź brzmi następująco: Andrè wybiera się na podbój świata, po sławę, i jak każdy artysta musi walczyć o uznanie, „legitymizację swojej twórczości” (P. Bourdieu). Albo przeciwnie: Andrè nie ma zapędów zdobywcy, zakłada hełm i chowa się w okopach, żeby stamtąd bronić swojej wolności artystycznej przed atakiem nikczemnego, przekupnego świata. Jest też wersja "alkoholowa”: Andrè z kolegami, co wieczór staje przeciwko oddziałom czerwonego wina, złotego piwa, whisky, wódki, nalewek niepewnego pochodzenia oraz innych trunków "wybuchowych" i walczy do ostatniej kropli (w takiej sytuacji bardzo dobrze jest mieć hełm na głowie). Najbardziej jednak interesująca zdaje się interpretacja pikielhauby i wojny w powieści Klinaua z punktu widzenia geopolityki (w jej wydaniu postmodernistycznym): Andrè zamierza wziąć udział w wielkiej bitwie dwóch cywilizacji, w decydującym starciu Wschodu i Zachodu.

W zależności od tego, kim jest rozmówca, Andrè wybiera sobie różne role i pozycje na polu walki. Niemieckiemu kierowcy, który podwozi go eleganckim samochodem, zwierza się, że wstąpił w niego duch pruskiego żołnierza:

...i teraz musi wyruszyć na wschód, żeby na powrót zaprowadzić do historycznej ojczyzny swój biedny, zagubiony w bagnach i stuleciach naród. I że przysiągł, że zanim nie zobaczy swojego bagiennego ludu radosnego i wolnego na brzegu ojczulka Renu, nie zdejmie z głowy pikielhauby. Jest to jednak bardzo trudna misja. Przeciwnik w hełmie żołnierza-wyzwoliciela usiłuje zwabić jego naród na brzeg mateczki Wołgi. Los narodu rozstrzygnie się podczas pojedynku olbrzymów i właśnie na ten pojedynek Andrè teraz zmierza ${ }^{3}$ (s. 44-45).

W Mohylewie szef, który obwiniał Andrè o dywersję ideologiczną, dowiaduje się z pisemnego wyjaśnienia, że w sytuacji, kiedy Białoruś jest otoczona ze wszystkich stron wrogimi państwami, każdy obywatel powinien nosić na głowie hełm:

Przedmiot ten byłby symbolem nieujarzmionego ducha naszego narodu, który wbrew wszelkim złośliwcom pewnie i uporczywie dąży do sobie tylko wiadomego celu. Ta pikielhauba, czy ordynarnie "hełm”, swoim zadartym w górę szpikulcem rzucałaby wyzwanie zmowie wrażych państw (s. 256).

Symbolicznym, a jednocześnie rzeczowym uosobieniem odwiecznej walki pomiędzy Wschodem a Zachodem o duszę Andrè i jego biednych rodaków są dwa

${ }^{3}$ A. Klinau, Shalom. Vaennyi roman. Dalej w artykule powieść A. Klinaua cytuję się według tego wydania, przekład cytatów na język polski M. Buchalik. 
lwy na emblemacie hełmu, którym bohater nadał charakterystyczne imiona: „Wallenrod" oraz "Światopełk": "Pośród bogatych zdobień igrały dwa dumne, złote lwy. Trzymały w łapach - albo próbowały wyrwać sobie nawzajem - złotą rycerską tarczę. Wyraźnie uprawiały przy tym geopolitykę, tarmosząc rozpłaszczoną na tarczy rybę." (s. 30). W wielu sytuacjach Wallenrod i Światopełk zachowują się jak żywi, reagują na niebezpieczeństwo, na przykład przy zbliżeniu się do białoruskiej granicy państwowej:

Jakby skuliły się w napięciu, mocniej wpiły pazury w tarczę i w trwożnym oczekiwaniu spoglądały po sobie, przeczuwając, że oto zbliżają się do dziwnej i tajemniczej krainy, pełnej jezior, bezkresnych lasów, bagien, niezliczonych wampirów, czerwononosych yoricków i błękitnych wodorostów, sączących otępiające miazmaty (s. 151).

Opozycja Wschód-Zachód wyraźnie przewija się przez całą powieść, a autor traktuje ją nie tylko żartobliwie. Jaskrawym przykładem odzwierciedlenia postmodernistycznej geopolityki są opisy miast oraz krajów, do których przyjeżdża Andrè. W świadomości głównego bohatera przebiega psychologiczne i estetyczne oswajanie środkowoeuropejskiej przestrzeni, realia geopolityczne transformują się w fantomy kulturologiczne.

Z tej perspektywy Pikielhauba otwiera się przede wszystkim nie jako "powieść wojenna”, ale jako "powieść podróżnicza”: fabuła utworu odsyła nas raczej do Odysei niż do Iliady (według klasyfikacji Borgesa).

Faktycznie, powieść traktuje o „powrocie bohatera”: z Bonn do Mohylewa przez Hanower, Berlin, Warszawę, Brześć i Mińsk. Akcja toczy się w siedmiu wyżej wymienionych miastach, które mogły posłużyć jako tytuły siedmiu rozdziałów utworu, gdyby autor był pisarzem-realistą i nie wyróżniał się bujną wyobraźnią. Powieść jednakże powstała pod gwiazdą postmodernizmu, wyobraźnia autora nie zna granic - dlatego to nie miasta, ale spożywane w nich trunki użyczają swoich nazw rozdziałom książki, wskrzeszając ducha niezapomnianego Wienieczki Jerofiejewa: „Chilijskie czerwone”, ,Jägermeister”, „Finlandia”, ,"Krupnik”, ,Skarb Radziwiłłów”, „Biała Ruś” i „Krzyżaczek”. Jedynie tytuł ostatniej części wyłamuje się z tego schematu: „Powrót idola”. Ten rozdział jednak pełni funkcje epilogu, bohater ląduje w izbie wytrzeźwień, gdzie dość trudno znaleźć napój alkoholowy.

W powieści Klinaua powstają malownicze portrety-opisy siedmiu wspomnianych miast. Przesuwając się z zachodu na wschód w ślad za bohaterem, czytelnik poznaje osobliwości topograficzne i architektoniczne, dowiaduje się o atmosferze każdego miasta, o jego miejscu w biografii oraz systemie wartości bohatera. Europejskie miasta zostały pokazane $\mathrm{w}$ powieści przez pryzmat świadomości człowieka wykształconego, twórczego, o niezwykłych zdolnościach obserwacyjnych, i co najbardziej istotne - takiego, kto się urodził w czasach sowieckich za „żelazną kurtyną", dzisiaj natomiast mieszka w ruinach socjalizmu. 
Zarówno z geograficznego, jak i z kompozycyjnego punktu widzenia logicznie byłoby zacząć zwiedzanie europejskich miast od Bonn, gdzie rozpoczyna się akcja powieści Klinaua. Taki początek byłby jednak niewybaczalnym błędem, ponieważ już na pierwszych stronach przed oczyma czytelnika rozwija się obraz innego ulubionego miasta naszego bohatera - Paryża. Paryż i Francja funkcjonują w utworze jako niedosiężne marzenie, jako uosobienie przestrzeni idealnej, najbardziej harmonijnej dla życia osoby twórczej z artystycznego punktu widzenia: „Francja... Cudowny, piękny kraj, fascynujący go od najmłodszych lat. Paryskie kawiarnie, wieża Eiffla, Moulin Rouge, plac Pigalle, Van Gogh, Degas, ToulouseLautrec..." (s. 8).

Nieprzypadkiem też imię głównego bohatera najczęściej zapisane jest w tekście na wzór francuski: Andrè. Takie imię dała mu artystka Franka, którą Andrè poznał w Bonn i od razu się w niej zakochał: „«André» lubił smutne oczy Franki, uważał ją za muzę i może nawet modelkę, która mogłaby kiedyś pozować mu do rzeźby. Samo jej imię kryło w sobie coś wzniosłego. Franka... Francja..." (c. 9).

Koledzy i żona mówią do niego "Andrej”, ,Andrejka”, ale kiedy bohater mówi tak o sobie w myślach, świadczy to o tym, że zrobił coś haniebnego, za co jest mu wstyd przed Andrè, przed Franką, przed Francją. Powstaje wyraźna opozycja pomiędzy "Andrè” i „Andrejką", gdzie wariant francuski reprezentuje najlepsze cechy bohatera (szlachetność, niezależność, odwagę), zaś białoruskie zdrobnienie najgorsze (prowincjonalizm, chamstwo, „жлобства”). „Andrejka” traktuje Frankę inaczej niż Andrè, mniej romantycznie: „Chciał zaciągnąć Frankę do łóżka: miesięczna abstynencja zaczynała już rzucać mu się na mózg" (s. 8)

Zachwyt Paryżem - symbolem kultury i cywilizacji zachodniej, kobiecego piękna i artystyzmu - może wydawać się w XXI wieku przejawem stereotypowego myślenia, tradycyjnego i nawet banalnego gustu. Już Wincenty DuninMarcinkiewicz ośmieszał w Idylli (1844) frankomanię dziewiętnastowiecznych Polaków i Białorusinów. W pewnym sensie bohater Klinaua przypomina bohatera Idylli, Karola Latalskiego, który patetycznie wołał:

O, czemu nasz kraj wciąż nie może stać się tak cywilizowany jak Francja? Wszystko tu takie ponure! Takie zabite dechami! [...] Nie ma to jak we Francji! Tam każda najprostsza wieśniaczka jest wyedukowana lepiej od tutejszej szlachcianki. O, Francjo, Francjo!4

Pod koniec XX wieku w literaturze białoruskiej powstał szereg tekstów, w których zburzono mit Paryża jako światowego cetrum sztuki i wzorca do naśladowania, w których stwierdza się ontologiczna równość między wierszami Rilkego a śpiewem babci z Polesia, znanymi w świecie martwymi naturami Matisse'a a "cikietkami" (kwiaty malowane na drewnianych deseczkach) nieznanych artystów z Dawidgródka. Poeta Leonid Drańko-Majsiuk w eseju Znużenie Paryżem

${ }^{4}$ V. Dunin-Martsinkevich, Zbor tvorau y doukh tamakh. T. 1. Minsk 2007, s. 109-110. 
[Стомленасиь Парыжам] spaceruje paryskimi uliczkami, tak jak kiedyś Guillaume Apollinaire, wplatając białoruskie wspomnienia i skojarzenia w gobeliny francuskich wrażeń, i dochodzi do wniosku, że:

Jeżeli naprawdę jesteśmy zapóźnieni w stosunku do naszych sąsiadów o sto, dwieście czy nawet więcej lat i męczymy się, brnąc na bosaka szlakiem historii, to nasze zapóźnienie (jestem pewien) bardzo przypomina tę zasadniczą różnicę, jaka niegdyś istniała pomiędzy męczącym dreptaniem bosych galilejskich rybaków a miarowym krokiem obutych rzymskich legionistów ${ }^{5}$.

Filozof Walancin Akudowicz w eseju Zburzyć Paryż [Разбурыць Парыж], biorąc za motto słowa Drańko-Majsiuka, za broń intelektualną zaś prace Derridy, Barthes'a i Lyotarda, uroczyście ogłosił wszystkim Białorusinom: „nie mamy wyboru: albo zburzymy Paryż, albo Paryż swoim ciężkim cieniem przygniecie nas na amen" 6 . Paryż rozumiany jako stolica wielkiej europejskiej narracji, symbol logicznego myślenia, w kategoriach którego Białoruś niezmiennie wyglądała na niedokończony projekt, państwo-outsidera, prowincję intelektualną i kulturową. Według Akudowicza spod ucisku wielkiej narracji europejskiej wybawi Białorusinów postmodernizm, którego nadejście na „ojczyste bagna” filozof bialoruski gorąco witał7.

Postać kultowa białoruskiej sztuki alternatywnej, pisarz-postmodernista Artur Klinau, łaskawie zezwolił swojemu bohaterowi, zwolennikowi awangardowej metody nekroromantyzmo-turboabstrakcjonizmu, zachować w świadomości dość staromodny, "niezburzony” dekonstrukcją obraz Paryża, nosić go w sercu jako wzniosłe marzenie, którego nie da się zrealizować - podobnie jak miłości do Franki (zrealizował się jedynie stosunek Andrejki). Jak gorzka kpina pod adresem opracowanego w literaturze białoruskiej tematu Paryża, brzmią w powieści Klinaua słowa Andrè o innym bohaterze, poecie i artyście Bujanie, który pracuje nad batalistycznym obrazem, poświęconym temu, jak „mendy wyruszają na podbój Paryża" (s. 92). Temat dzieła przypomina żartobliwą fantasmagorię z eseju Akudowicza o kolumnie traktorów "Białoruś”, która idzie na Paryż, żeby zasadzić na Polach Elizejskich białoruskie ziemniaki ${ }^{8}$.

Inaczej ma się sprawa z Bonn, które w odróżnieniu od dalekiego Paryża, miasta marzeń bohatera, jest całkowicie realne: tutaj Andrè mieszkał przez cały miesiąc na plenerze artystycznym, tu toczy się akcja pierwszego rozdziału książki. Jednak realność tego miasta jawi się bohaterowi nie do końca prawdziwa w porównaniu do tej rzeczywistości, która Andrè zostawił w rodzimym kraju:

\footnotetext{
${ }^{5}$ L. Dranko-Maisiuk, Akropol. Minsk 1994, s. 115-116.

6 V. Akudovich, Razburyts Paryzh. Minsk 2004, s. 132.

${ }^{7}$ Ibidem, s. 120-140.

8 Ibidem, s. 133.
} 
Przypominało mu duże, zaciszne sanatorium, do którego czasem warto wpaść, żeby podleczyć udręczony „Krzyżaczkami” i niewygodami życia po tej stronie płotu układ nerwowy. Zresztą wszystkie niemieckie miasta - oprócz Berlina - przypominały mu sanatoria. Kiedy od czasu do czasu André przyjeżdżał do Niemiec, wręcz zdawało mu się, że jest żołnierzem, który przyjechał z frontu na przepustkę gdzieś na głębokie tyły, żeby wypocząć i nabrać nowych sił. Ale za parę dni ostatni wieczorny pociąg znowu zabierze go na wschód, do śmierdzących i brudnych okopów, tam gdzie pełno wszy i gdzie strzelają - na pierwszą linię (s. 20).

Znów mamy do czynienia z opozycją Wschód-Zachód, gdzie Zachód kojarzy się z pokojem, tyłami, sanatorium, Wchód zaś z wojną, okopami i wszami (autor wyraźnie gustuje w rozmaitych podgatunkach owych insektów). Opozycja ta unaocznia się również w doborze trunków (w Niemczech i w Polsce Andrè pije szlachetne gatunki, na Białorusi natomiast podejrzane wynalazki typu "Skarb Radziwiłłów” czy „Krzyżaczek”), a także w upodobaniach erotycznych (Andrè brzydzi się dziewczynami w stylu Turgieniewa, pociągają go typ kobiety z filmów Fassbindera). Na dworcu w Hanowerze Andrè poznaje „aniołka Fassbindera”, Ingrid, która pierwszej nocy zostaje jego towarzyszką broni i już następnego dnia razem ruszają do Berlina. W Hanowerze bohater spędził tylko jedną noc, dlatego miasto pojawia się w tekście fragmentarycznie (dworzec nocą, mieszkanie boyfrenda Ingrid), ale też może dlatego, że właśnie to miasto jest dobrze „oswojone” przez literaturę białoruską: przypomnijmy esej Uładzimira Arłoua Niech żyją hanowerskie wrony [Няхай жывуиь гановерскія вароны] czy tom poetycki Hanowerskie linie przerywane [Гановерскія пункиіры] Alesia Razanaua, który przez kilka lat mieszkał w Hanowerze („Kiedy ty karmiłeś ptaki w Hanowerze, tutaj umierała epoka9” napisze póżniej w poetyckim liście do Razanaua Ihar Babkou).

W rozdziale „Finlandia” akcja toczy się w Berlinie i czytelnik wreszcie się dowiaduje, dlaczego to miasto nie kojarzyło się bohaterowi tak jak inne niemieckie miasta z sanatorium: przypominało mu Petersburg czasów jego młodości - te same obdarte, wyliniałe budynki, śmierdzące klatki schodowe i karaluchy w mieszkaniach (jeszcze jeden lubiany przez autora gatunek insektów). Tak samo jak w Petersburgu, fatalne warunki mieszkaniowe na peryferiach miasta i przepych turystycznego centrum łączą się w specyficzną całość: "André doszedł do Wyspy Muzeów i skamieniał z zachwytu. Największe wrażenie robiła tu nawet nie architektura, uderzająca potęgą i rozmachem, ale atmosfera, która spowijała ogromne pałace" (s. 83).

Ze wszystkich portretów-charakterystyk miast w powieści Pikielhauba opis Berlina jest najbardziej rozbudowany i malowniczy, daje się odczuć wykształcenie architektoniczne Klinaua oraz jego zdolności obserwacyjne. Odtwarzając koloryt "kolonii hobbitów", białoruskich artystów mieszkających w budynku Tacheles,

${ }_{9}^{9}$ I. Babkou, Zasynats, prachynatstsa, slukhats galasy ryb. Minsk 2009, s. 12. 
autor wykazuje dobra znajomość realiów i niesamowite poczucie humoru (obraz poety Bujana, prototypem którego był Źmicier Wiszniou, jest jednym z najlepszych w całej powieści).

Nie tylko zdolności obserwacyjne, ale też wyobraźnia autora aktywnie uczestniczy w tworzeniu literackiego obrazu Berlina, gęsto owiniętego we wrażenia Andrè, poznającego niemiecką literaturę i filozofię:

Zdawała się kwintesencją pruskiego ducha, tym, co niosło w sobie obraz Niemiec, namalowany $\mathrm{w}$ jego wyobraźni jeszcze kiedy był dzieckiem, kiedy z zapartym tchem czytał Goethego, Kleista, Hoffmana i innych romantyków niemieckich i kiedy próbował wgryźć się w Krytykę czystego rozumu Kanta (s. 83).

Przy próbie zdefiniowania metody twórczej, wykorzystywanej przez Klinaua w opisach europejskich miast, przychodzi mi na myśl fragment z cytowanego wyżej eseju Akudowicza:

...Człowiek stopniowo oduczył się widzieć to, co jest, w jego konkretno-rzeczywistej istocie, a potem $\mathrm{w}$ ogóle widzieć okiem. Od dawna już jedynie patrzy okiem, a widzi rozumem. [...] Mierzymy topografię rzeczywistości nie jej własną miarą, ale skalą wypracowaną $\mathrm{w}$ „przestrzeni” a-rzeczywistości ${ }^{10}$.

Również rosyjski Petersburg we wspomnieniach, majaczeniach czy sennych koszmarach bohatera jawi się nie tylko jako miasto jego młodości, część realnej biografii, ale też jako miasto Dostojewskiego, gdzie z bram wyskakują duchy Raskolnikowa, starej lichwiarki i Swidrigajłowa. Petersburg ciężkich wspomnień, podobnie jak Paryż niezrealizowanych marzeń, zajmuje w świadomości bohatera istotne miejsce, kojarzy się z niebezpieczeństwem, zagrożeniem, oddechem Imperium (Moskwy Andrè po prostu nie lubił, dlatego w powieści prawie nie ma o niej wzmianek).

Jeszcze jedno odzwierciedlenie opozycji Wschod-Zachód w utworze Klinaua to przeciwstawienie europejskiej i rosyjskiej filozofii i kultury: Hoffmanna i Turgieniewa, Kanta i Dostojewskiego, Marksa i Bierdiajewa. Zarówno autor, jak i jego bohater zdają się podzielać znaną tezę Ihnata Abdzirałowicza o specyfice Białorusi jako kulturowej przestrzeni pomiędzy: pomiędzy Wschodem a Zachodem, pomiędzy cywilizacją łacińską a bizantyjską, pomiędzy katolicyzmem a prawosławiem. Charakterystyczna jest pod tym względem rozmowa Ingrid $\mathrm{z}$ Andrè na dworcu w Hannowerze:

- Skąd jesteś? - zapytała, kiedy po akcencie zorientowała się, że nie jest Niemcem.

- Z Białorusi.

- A gdzie to jest?

${ }^{10}$ V. Akudovich, op. cit., s. 123. 
- Na wschodzie. Zaraz za Polską.

- W Rosji?

- Pomiędzy. Na linii frontu.

- Aaa! Czarnobyl! (s. 62)

A zatem Białoruś to linia frontu. Również Polska w świadomości bohatera jest krajem pogranicznym: już nie Wschód, ale jeszcze nie Zachód. W odróżnieniu od Andrè jego polski kolega Jacek dość szybko poznał prawa rynku i błyskawicznie zrobił karierę artystyczną, rysując akty w środkach komunikacji miejskiej. Twórczością Jacka interesują się wpływowe kuratorki i największe galerie w Europie; Jacek dawno już wyszedł z brudnych okopów, stając się może szczęśliwym zwycięzcą, a może zwyciężonym w tej wielkiej wojnie, którą wciąż musi prowadzić Andrè. Z drugiej strony, w Warszawie na każdym kroku widać ślady innej wojny, wyraźnie odczuwa się oddech historii: starsza pani radzi bohaterowi zdjąć pikielhaubę, żeby nie budzić nieprzyjemnych skojarzeń u jej rodaków, a Pałac Kultury i Nauki przesyła gorące pozdrowienia od ojca narodów, Józefa Stalina.

Jednak w obrazie Polski, postrzeganej przez bohatera, dominuje wizja dawnej Rzeczypospolitej, wspólnego państwa Polaków, Litwinów, Białorusinów i Ukrainców; nieprzypadkowo też ulubionym trunkiem Andrè nie jest „Wyborowa” ani "Żytnia”, ale „Krupnik”:

Był to starolitewski krupnik, mocna i smaczna nalewka na miodzie - napój niegdyś popularny za Bugiem, na wschodnich rubieżach Rzeczypospolitej. Później jego receptura popadła tam w zapomnienie i robiono go już tylko w Polsce. Za każdym razem, kiedy André wracał do Korony, spośród wszystkich napitków wybierał właśnie krupnik. Każdy jego łyk zdawał mu się pozdrowieniem $\mathrm{z}$ tej odległej epoki, kiedy ich kraj rósł $\mathrm{w}$ siłę i rozciągał się od morza do morza, a w miastach, zamkach i miasteczkach kwitł smaczny jak miód złoty wiek sarmackiej kultury (s. 166).

W Warszawie, mimo kojącego działania starolitewskiego krupniku, Andrè przeżywa załamanie nerwowe i mimowoli urządza awanturę w pracowni Jacka, który serdecznie przyjął dawnego przyjaciela i nawet próbował mu pomóc, poznając go z wpływowymi kuratorkami. Jedną z przyczyn załamania jest pobłażliwe współczucie kuratorek, wywołane tym, że Andrè pochodzi z nieszczęsnego kraju, w którym rządzi „dyktaciur”, a po ulicach chodzą niedźwiedzie, najwyraźniej przeniesione z Moskwy. Z podobnym podejściem do ojczyzny bohater spotyka się przez całą swoją podróż z Bonn do Brześcia: Czarnobyl, dyktatura, bieda, nieszczęsny naród, który przychylnie zerka w stronę Rosji, zamiast naśladować cywilizowany Zachód.

Właśnie artystyczne ukazywanie zachodnich stereotypów, dotyczących Białorusinów i ich posłusznej gotowości wpisywania się w owe stereotypy, byle wyciągnąć korzyści z image'u „nieszczęsnego narodu”, jest główną zasługą autora Pikielhauby. Metaforycznym wcieleniem podobnego systemu stereotypów i mode- 
lu relacji między Europejczykami a Białorusinami stało się porównanie Białorusinów do hobbitów, zaś totalitarnego rządu - do Mordoru:

Reprezentował malutki, zapomniany przez Boga kraj, zwinięty gdzieś pod płotem Europy. Ludziom z tej strony płotu kraj ów zdawał się jakimś strasznym Mordorem, okupowanym przez orki, które nic tylko znęcają się nad biednymi hobbitami, uciskają je i łamią ich prawa obywatelskie.

Żeby pomóc nieszczęsnym hobbitom, od czasu do czasu zapraszano je do Europy na jakieś seminarium i uświadamiano, jak mogą zwyciężyć orki w wyborach i zmienić Mordor w hobbicią demokrację, albo na festiwal literacki, żeby posłuchać, jak brzmi ich dziwny, archaiczny język, albo - jak w tym przypadku - na plener rzeźbiarski, żeby przekonać się, że hobbity w ogóle jeszcze istnieją i nawet potrafią wytwarzać dzieła sztuki (s. 10).

Problem bohatera oraz autora powieści polega na tym, że ich obraz Białorusi mało czym różni się od stereotypów, funkcjonujących w świadomości Europejczyków; nie formuje się wbrew ich oczekiwaniom, wręcz przeciwnie: bardzo odpowiada ich fobiom, żalom i współczuciu.

W myślach Andrè niejednokrotnie narzeka na swój los, przekonany, że jego genialne projekty artystyczne robią klapę tylko dlatego, że urodził się $\mathrm{w}$ tym strasznym miejscu, za płotem, na zadupiu. Ubolewa nad swoim przyjacielem, malarzem Chwiedarem: „Gdyby służył w innej armii - francuskiej czy niemieckiej pewnie nosiłby już pagony, jeśli nie generała, to przynajmniej pułkownika albo majora. Ale w Mordorze nie było generałów sztuki, a dokładniej rzecz ujmując, było kilku wyznaczonych odgórnie" (s. 88).

Artur Klinau w drugiej, ,białoruskiej” części powieści przedstawia obraz mało pocieszający, prawie apokaliptyczny, który wydaje się prostą drogą prowadzić do szaleństwa nie tylko bohatera, ale też czytelnika Pikielhauby. W Brześciu autor kieruje swojego bohatera do brudnego bufetu dworcowego i każe wysłuchać spowiedzi pijaczki Kaciaryny, a przy okazji dowiaduje się o istnieniu taniego napoju o szlachetnej nazwie „Skarb Radziwiłłów”. Brzeską Kaciarynę - nie wiadomo, czy jest to postać realna, czy bohaterka zapożyczona z powieści Dostojewskiego trudno porównać z Ingrid, bywalczynią dworca w Hanowerze (tak samo jak nie da się porównać "Skarbu Radziwiłłów” do "Jägermeistra”). Architektonicznemu wizerunkowi Mińska autor poświęca kilka poetyckich akapitów w stylu książki Mińsk. Przewodnik po Mieście Stońca, jednak główną treść "mińskiego" rozdziału stanowi wizyta Andrè w sklepie monopolowym i ucieczka przed tajemniczymi typami (prawdopodobie współpracownikami KGB). Akurat tego dnia, kiedy bohater przybywa do stolicy Białorusi, w mieście odbywa się nielegalny strajk hadlarzy na placu Kastrycznickim, ulicami jeżdżą kolumny autobusów z funkcjonariuszami służb specjalnych i ciężarówki z żołnierzami, na podwórkach na aresztowanych uczestników akcji czekają duże czarne „suki”. Naprawdę „dyktaciur"! 
Po powrocie do rodzinnego Mohylewa Andrè trafia do strefy mutantów, do niedorzecznych dzielnic z ponurymi blokowiskami bez śladu jakiejkolwiek architektury, z ciemnymi śmierdzącymi klatkami, zdemolowanymi windami, z widniejącymi na ścianach nieprzystojnymi wyrazami. Musimy oddać bohaterowi sprawiedliwość: mimo wszystko kocha swoje miasto, nie za resztki byłego piękna (na przykład widok na Dniepr), ale za jego brzydotę: „W nędzy nieudanego dzieła postrzegał prawdziwą stronę życia. Było tu więcej głębi, szczerości i doskonałości, niż w miastach pięknych, dumnych i monumentalnych. I taki też był właśnie, jak sądził, zamysł Boga; Boga, który świadomie stworzył nieudany, zdeformowany świat" (s. 243).

Dysharmonijny wizerunek rodzinnego miasta Andrè można uznać za przejaw jakiejś specjalnej woli Wszechmogącego, gdyby zaś próbować znaleźć winnych na ziemi, bohater bez wahania wskazuje Rosję, która jego zdaniem niewątpliwie przyczyniła się do upadku Mohylewa:

Kiedyś - ze trzysta lat temu - miał urok europejskiego miasta: mnóstwo barokowych kościołów, wieże zamku, ratusz, wąskie uliczki i kamienice ze stromymi, krytymi dachówką dachami. Ale potem przyszły światopełki i miasto ugrzęzło w szarej prowincjonalnej nudzie. Kościoły zburzono, zamek popadł w ruinę, ratusz wysadzono w powietrze, kamienice przebudowano, strome dachy zamieniono płaskimi, a dachówkę blachą; krótko mówiąc, kwitnące miasto zmieniło się w zwykłego, zbędnego nieudacznika, zagubionego gdzieś na peryferiach Imperium Rosyjskiego (s. 241).

Tragedia bohatera polega na tym, że racjonalnie zwraca się on ku kulturze zachodu, ale psychologicznie, charakterologicznie grzęźnie we wschodniej mentalności: nieprzypadkowo w roli jego wirtualnego rozmówcy występuje Fiodor Dostojewski.

Symptomatyczne, że mimo antyrosyjskich poglądów André w młodości próbował przeprowadzić się do Petersburga, ale tamtejsi artyści go nie zaakceptowali. Nieswojo czuje się również w czyściutkich, sanatoryjnych Niemczech i przyznaje, że nie chciałby zostać tam na stałe. A Białorusi, na której mógłby być szczęśliwy jako człowiek i potrzebny jako artysta, już (albo jeszcze) nie ma.

$\mathrm{W}$ rezultacie bohater Pikielhauby znajduje się $\mathrm{w}$ naprawdę tragicznej sytuacji: pomiędzy, na linii frontu, a konkretnie: pod mostem, łączącym prawy i lewy brzeg Dniepru, łączącym Wschód i Zachód. André zamierza wysadzić ten most w powietrze. Dlaczego? Czy tylko na znak protestu? A może jest to jego świadomy wybór geopolityczny? 